\title{
Pertanggungjawaban Pidana Korporasi terhadap Pemalsuan Data Ekspor Zinc Ash yang Dilakukan oleh PT Marakes Jaya Abadi di KPPBC Belawan
}

\section{Corporate Criminal Responsibility against Forgiving of Ash Zinc Export Data Conducted by PT Marakes Jaya Abadi at KPPBC Belawan Research Study}

\author{
Tigor Maruhum Sitorus ${ }^{1)}$, Ediwarman$^{2)}$ \& Citra Ramadhan ${ }^{1) *}$ \\ 1) Program Studi Magister Ilmu Hukum, Universitas Medan Area, Indonesia \\ 2)Universitas Sumatera Utara, Indonesia
}

Diterima: 15 Juli 2021; Direview: 02 Agustus 2021; Disetujui: 30 September 2021

*Coresponding Email: Citraramadhan@staff.uma.ac.id

\begin{abstract}
Abstrak
Artikel ini membahas aturan hukum yang mengatur tentang pertanggungjawaban korporasi dalam peraturan perundang-undangan terhadap pemalsuan data ekspor zinc ash, dan bagaimana faktor penyebab terjadinya pemalsuan data zinc ash yang dilakukan oleh korporasi serta bagaimana kebijakan hukum pidana terhadap korporasi yang melakukan pemalsuan data ekspor. Metode yang digunakan dalam penulisan ini yaitu metode penelitian hukum Normatif. Penelitian ilmu hukum normatif adalah pengkajian terhadap bahan-bahan hukum, baik bahan hukum primer maupun bahan hukum sekunder. Adapun faktor penyebab terjadinya pemalsuan data zinc ash yang dilakukan oleh korporasi adalah sebagai berikut: Faktor-faktor penyebab terjadinya pemalsuan dokumen pabean, antara lain adalah: (a) Geografis, (b) Pasar produksi, (c) Masyarakat. Upaya penanggulangan tindak pidana pemalsuan data ekspor oleh tim Penindakan dan Penyidikan Bea dan Cukai Tipe Madya Pabean (KPPBC TMP) Belawan telah mencerminkan kedua jalur penanggulangan, yaitu jalur penal yang bersifat represif dan non-penal yang bersifat preventif.

Kata Kunci: Pertanggungjawaban Pidana; Korporasi; Pemalsuan Data Ekspor.
\end{abstract}

\begin{abstract}
This article discusses the legal rules governing corporate liability in laws and regulations against falsification of zinc ash export data, and how the factors that cause zinc ash data falsification by corporations and how the criminal law policies against corporations falsify export data. The method used in this paper is a normative legal research method. Normative legal research is the study of legal materials, both primary legal materials and secondary legal materials. The factors causing the falsification of zinc ash data by corporations are as follows: The factors causing the falsification of customs documents, among others are: (a) Geographic, (b) Production market, (c) Society. Efforts to tackle the crime offalsifying export data by the Belawan Intermediate Customs and Excise Investigation and Customs Enforcement Team (KPPBC TMP) in Belawan have reflected both ways of countermeasures, namely the repressive penal route and the preventive non-penal route.
\end{abstract}

Keywords: Criminal Liability; Corporations; Falsification of Export Data.

How to Cite: Sitorus, T.M., Ediwarman, \& Ramadhan, M.C. (2021). Pertanggungjawaban Pidana Korporasi Terhadap Pemalsuan Data Ekspor Zinc Ash Yang Dilakukan Oleh PT Marakes Jaya Abadi di KPPBC Belawan, Journal of Education, Humaniora and Social Sciences (JEHSS). 4(2): 1154-1161. 


\section{PENDAHULUAN}

Wilayah Negara Kesatuan Republik Indonesia (NKRI) merupakan salah satu unsur negara yang merupakan satu kesatuan wilayah daratan, perairan pedalaman, perairan kepulauan, dan laut territorial, beserta dasar laut dan tanah dibawahnya, serta ruang udara diatasnya, termasuk seluruh sumber kekayaan yang terkandung di dalamnya (Pasal 1 angka 1 Undang-Undang Nomor 43 Tahun 2008 tentang Wilayah Negara). Berdasarkan konsepsi TZMKO Tahun 1939, lebar laut wilayah perairan Indonesia hanya meliputi jalur laut yang mengelilingi setiap pulau atau bagian pulau Indonesia, lebar laut hanya 3 mil laut. Hal ini sesungguhnya dapat mengancam kepentingan, keselamatan, dan keamanan Republik Indonesia, karena di antara pulau-pulau di Indonesia terdapat perairan bebas (laut internasional) untuk lalu lintas kapal-kapal negara manapun, baik kapal niaga, kapal perang, kapal penangkap ikan, termasuk kapal selam berlayar di perairan tersebut (Arfin, 2019).

Laut sebagai wilayah teritorial, merupakan daerah yang menjadi tanggungjawab sepenuhnya negara yang bersangkutan dengan penerapan hukum yang berlaku di wilayahnya yaitu hukum nasional negara yang bersangkutan. Batas laut teritorial sebagaimana disinggung di muka, hampir setiap negara lautan mempergunakan prinsipnya untuk menentukan lebar laut teritorial dengan tetap memperhatikan konvensi hukum laut internasional yang berlaku (Subagyo Joko, 2009). Terutama setelah lahirnya Konvensi Internasional Perserikatan Bangsa-Bangsa (PBB) mengenai hukum laut (United Nation Convention on The Law of The Sea) pada tahun 1982, arti penting hukum laut semakin menonjol. Peraturan perundang-undangan maritim meliputi substansi sebagai berikut: 1) Keselamatan berlayar, 2) Pelayaran, 3) Pengawakan kapal, 4) Pencemaran laut, 5) Peraturan ekonomi, dan 6) Hukum perdata maritim. Dalam kesempatan lain, dijelaskan oleh pakar hukum, yang dimaksud dengan hukum angkutan laut Indonesia ialah hukum Indonesia yang mengatur penyelenggaraan angkutan barang dan orang melalui laut (Sentosa, 2019).

Penyelundupan yaitu pelanggaran dalam impor atau ekspor, khususnya barang-barang yang ditetapkan kena bea masuk atau pajak oleh petugas bea dan cukai atau kebiasaan tanpa membayar bea pajak yang telah ditetapkan bea dan cukai. Sanksi yang tepat diberikan kepada penyelundup adalah penyitaan barang atau dapat dikenakan untuk membayar denda tiga kali lipat, atau suatu jumlah yang ditetapkan oleh hukum (yang mana yang lebih besar), pelanggaran boleh sebagai alternatif, atau apalagi menerima hukuman pidana dalam waktu tertentu (wibowo yudi, 2018). Dalam era globalisasi dan perdagangan bebas sekarang ini, arus lalu lintas orang semakin tinggi. Dampak yang ditimbulkan pun semakin bervariasi. Menghadapi kenyataan ini, masing-masing negara menyikapi dengan hati-hati dan bijaksana supaya tidak berdampak negatif kepada sektor bisnis atau perekonomian suatu negara atau hubungan yang kurang harmonis antar Negara, sehingga pengoptimalan disesuaikan dengan kondisi sosial politik masing-masing Negara (Sihar, 2009).

Pemerintah seharusnya menindak tegas setiap pelanggaran di bidang ekonomi, salah satunya adalah tindak pidana di bidang kepabeanan yaitu tindak pidana penyelundupan. Hal tersebut diatur dalam peraturan perundang-undangan sejak zaman Belanda yaitu Staatsblads No. 240 tahun 1882, kemudian berturut-turut menjadi Undang-Undang Darurat No. 7 tahun 1955 Tentang Tindak Pidana Ekonomi, Undang-Undang No. 8 tahun 1958 Tentang Lembaran Penambahan Undang-Undang Darurat No.7 tahun 1955, Undang-Undang No.10 tahun 1995 Tentang Kepabeanan dan Undang-Undang No. 17 tahun 2006 Tentang Perubahan Atas UndangUndang No. 10 Tahun 1995 Tentang Kepabeanan. Dilihat dari penggolongan delik pidana, UndangUndang Nomor 17 Tahun 2006 membagi secara jelas perumusan tindak pidana menjadi dua, yaitu pelanggaran dan Tindak Pidana (Kejahatan) Kepabeanan. Lebih spesifik lagi Tindak Pidana Kepabeanan dirinci menjadi Tindak Pidana Penyelundupan sebagaimana dimaksud dalam pasal 102, pasal 102A, 102B, 102C, 102D dan pasal 103 Undang-Undang Kepabeanan. (Widya, 2006).

Diadopsinya korporasi sebagai subjek hukum pidana di Indonesia, terlihat dari berbagai Undang-Undang yang dibuat akhir-akhir ini. Sebenarnya pendirian korporasi dapat menjadi tindak pidana untuk pertama kalinya telah muncul pada tahun 1951, yaitu ketika diberlakukannya 
Undang-Undang Darurat No. 17 Tahun 1951 tentang Penimbunan Barang-barang. Namun konsep pertanggungjawaban pidana korporasi dari Undang-Undang tersebut tidak berkembang (Sutan, 2017). Melalui konvensi ini diharapkan peningkatan kinerja dalam pelayanan di bidang pabean, perdagangan internasional, bisnis internasional dan investasi akan terwujud, sehingga visi DJBC yang dalam jangka panjang ingin setara dengan kepabeanan di negara-negara maju akan tercapai sebagaimana diharapkan (Ali, 2010).

Teori merupakan pengetahuan ilmiah yang mencakup penjelasan mengenai suatu sektor tertentu dari sebuah disiplin keilmuan. Teori berasal dari kata theoria dalam bahasa latin yang berarti perenungan, yang pada gilirannya berasal dari kata thea dalam bahasa Yunani yang secara hakiki menyiratkan sesuatu yang disebut realitas (Rizkan, 2020). Teori dan penelitian harus secara bersama berfungsi menambah pengetahuan ilmiah, seorang peneliti ilmu hukum terutama dalam penelitian ilmu hukum empiris, tidak boleh menilai teori terlepas dari kenyataan fakta-fakta hukum yang ada ditengah masyarakat (Johan bahder, 2008). Teori yang digunakan dalam penelitian ini adalah: Teori Pertanggungjawaban pidana perusahaan Corporation Criminal Liability) sebagai teori utama (Grand Theory), dan teori Penegakan Hukum (Middle Theory), Teori Pemidanaan sebagai (Applied Theory).

Berdasarkan penelusuran kepustakaan terdapat judul yang berkaitan dengan "Pertanggungjawaban Pidana Korporasi Terhadap Pemalsuan Data Ekspor Zinc ash Yang Dilakukan Oleh PT Marakes Jaya Abadi (Studi Riset Kppbc Belawan)”. Penelitian yang pernah dilakukan adalah sebagai berikut: Tesis berjudul "Analisis Hukum Tindak Pidana Penyelundupan Oleh Korporasi Berdasarkan Pasal 102 Undang-Undang Republik Indonesia Nomor 17 Tahun 2006" yang ditulis oleh Samsir, Npm: 201420251026, MH, Universitas Bhayangkara Jakarta Raya Jakarta dengan fokus perumusan yang dikaji: (a) Bagaimana faktor-faktor yang sering menjadi penyebab terjadinya tindak pidana penyelundupan oleh korporasi? (b) Bagaimana upaya pencegahan tindak pidana penyelundupan berdasarkan Pasal 102 Undang-Undang Nomor 17 Tahun 2006?

Adapun rumusan masalah dalam penelitian ini yaitu: (a) Bagaimana aturan hukum yang mengatur tentang pertanggungjawaban korporasi dalam peraturan perundang-undangan terhadap pemalsuan data ekspor zinc ash? (b) Bagaimana faktor penyebab terjadinya pemalsuan data zinc ash yang dilakukan oleh korporasi? (c) Bagaimana kebijakan hukum pidana terhadap korporasi yang melakukan pemalsuan data ekspor?

\section{METODE PENELITIAN}

Jenis penelitian dalam penulisan ini adalah penelitian hukum normatif. Penelitian hukum normatif atau doktriner, yaitu penelitian hukum yang mempergunakan penelitian sumber data sekunder (Ediwarman, 2020). Penelitian normatif juga ditunjang dengan data emperikal agar penelitinya mendapat hasil yang memadai sebagai kandungan ilmiah (Johan Bahder, 2008). Metode pendekatan adalah cara pandang peneliti dalam memilih spektrum ruang bahasan yang diharap mampu memberi kejelasan uraian dari suatu substansi karya ilmiah (Diantha, 2019). Pendekatan dalam penelitian ini menggunakan metode pendekatan normatif atau legal research, pendekatan ini terbagi atas pendekatan Undang-Undang (Statute Approach), metode pendekatan kasus (Case Approach). Penelitian ini mengambil lokasi di Sumatera Utara yang bertempat di KPPBC TMP Belawan, pertimbangan mengenai dipilihnya lokasi penelitian ini yaitu dengan melakukan penelitian di lokasi ini penulis dapat memperoleh data yang lengkap, akurat dan memadai. Oleh karena penelitian ini menggunakan jenis penelitian hukum normatif maka pengumpulan data dilakukan dengan studi kepustakaan dan wawancara.

Sumber dan jenis data dalam penelitian tesis ini dilakukan dengan mengumpulkan data-data primer dan data sekunder yaitu: (1) Data primer, pengumpulan data dilakukan dengan penelitain lapangan. Hasil penelitian ini didapat melalui wawancara. (2) Data sekunder, diperoleh melalui penelitian kepustakaan yaitu literatur-literatur dan peraturan perundang-undangan yang berhubungan dengan permasalahan yang akan diteliti. (3) Bahan hukum tersier, yaitu bahan yang memberikan petunjuk maupun penjelasan terhadap bahan hukum primer dan bahan hukum sekunder (Amiruddin, 2018). 
Analisis diartikan sebagai penyelidikan terhadap suatu peristiwa untuk mengetahui keadaan yang sebenarnya, sebab musabab, atau duduk perkaranya. Analisis data merupakan penelaahan dan penguraian data hingga menghasilkan kesimpulan. Analisis data berisi uraian tentang caracara analisis, yakni bagaimana memanfaatkan data yang terkumpul untuk dipergunakan dalam memecahkan masalah dalam peneliti yang dilakukan (Elisabeth, 2018).

\section{HASIL DAN PEMBAHASAN}

\section{Aturan Hukum Perundang-Undangan Terhadap Pemalsuan Data Ekspor Zinc Ash Undang-} Undang No. 1 Tahun 1946 Tentang Kitab Undang-Undang Hukum Pidana

Korporasi merupakan badan hukum dan non badan hukum, berupa sekumpulan orang yang dipersamakan oleh hukum sebagai orang (naturjilk person) yang dapat melakukan perbuatan hukum, seperti membuat perjanjian, melakukan jual-beli, dituntut dan menuntut di depan pengadilan. Oleh sebab itu dapat dimintakan kepadanya pertanggungjawaban hukum. Jika korporasi sebagai subjek hukum, maka siapa yang dapat dimintai pertanggungjawaban. Pihak yang dapat dimintai pertannggungjawaban pidana yang dilakukan oleh korporasi dalam peraturan perundang-undangan di luar KUHP dapat diklasifikasikan sebagai berikut: Pengurus dan orang lain yang mewakili pengurus, seperti terdapat pada Pasal 15 ayat (3) Undang-Undang Darurat No. 7 Tahun 1955 dan Pasal 20 Undang-Undang No. 20 Tahun 2010. Korporasi, ketentuan ini diatur dalam Pasal 15 ayat (1) Undang-Undang Darurat No. 7 Tahun 1955, Pasal 20 Undang-Undang No. 20 Tahun 2001, Pasal 6 Undang-Undang No. 8 Tahun 2010. Pengendali korporasi seperti tercantum dalam Pasal 6 ayat (1) Undang-Undang No. 8 Tahun 2010. Korporasi dan pengurus hal ini misalnya, dianut dalam Undang-Undang Darurat No. 7 Tahun 1955 dan Undang-Undang No. 20 Tahun 2001 (Amir, 2020).

\section{Undang-Undang Darurat No. 17 Tahun 1951 tentang Penimbunan Barang-barang.}

Berbicara mengenai pertanggungjawaban pidana, maka tidak dapat dilepaskan dengan tindak pidana. Walaupun pengertian tindak pidana tidak termasuk masalah pertanggungjawaban pidana. Tindak pidana hanya merujuk kepada dilarangnya suatu perbuatan. Dasar adanya tindak pidana adalah asas legalitas, sedangkan dasar dipidananya pembuat adalah asas kesalahan. Hal ini berarti bahwa pembuat tindak pidana hanya akan dipidana jika ia mempunyai kesalahan dalam melakukan tindak pidana tersebut. Dalam Undang-Undang itu apa yang baru ditentukan adalah mengenai siapa yang harus tampil di muka pengadilan apabila korporasi didakwa sebagai pelaku tidan pidana. Menurut Pasal 12 ayat (1) Undang-Undang tersebut, bilamana suatu tuntutan hukum dilakukan terhadap suatu badan hukum, maka badan hukum ini selama tuntutan diwakili oleh seorang pengurus yang jika perlu ditunjuk oleh kejaksaan. Sementara itu, menurut pasal 12 ayat (2), surat-surat pengadilan yang berhubungan dengan tuntutan ini diberitahukan dengan resmi di kantor badan hukum atau di rumah pengurus itu (Nasution, 2015).

\section{Undang-Undang Republik Indonesia Nomor 17 Tahun 2006 tentang Perubahan Atas Undang-Undang Nomor 10 Tahun 1995 tentang Kepabeanan}

Objek pengenaan sanksi administrasi hanya dikenakan terhadap pelanggaran yang diatur dalam Undang-Undang Nomor 17 Tahun 2006 tentang Perubahan Atas Undang-Undang Nomor 10 Tahun 1995 tentang Kepabeanan. Tujuan penerapan sanksi administrasi untuk memulihkan hakhak negara dan menjamin ditaatinya aturan-aturan yang secara tegas telah diatur dalam ketentuan perundang-undangan. Dengan demikian, sanksi administrasi harus merupakan sarana fiskal yang dapat dilaksanakan secara efektif dan efisien. Penerapan sanksi administrasi pada hakikatnya merupakan kewajiban yang dapat memberatkan mereka yang terkena, maka penerapannya harus memenuhi kriteria yang transparan agar dapat dicegah terjadinya ketidakpastian dalam menetapkan sanksi administrasi tersebut.

\section{Faktor Penyebab Terjadinya Pemalsuan Data Zinc Ash Yang Dilakukan Oleh Korporasi}

Ekspor dalam dunia perdagangan merupakan penjualan produk dari dalam negeri ke luar negeri serta merupakan target pemasaran suatu negara. Pengertian ekspor adalah pengangkutan 
barang dalam jumlah tertentu dari suatu negara ke negara lain baik untuk diperdagangkan maupun tidak untuk diperdagangkan, dengan memenuhi kewajiban kepabeanan yang telah ditentukan.

Dengan berkembangnya perdagangan lintas negara yang dipengaruhi oleh globalisasi, untuk barang-barang ekspor lebih dikonsentrasikan ke arah spesialisasi dengan memberikan beberapa fasilitas perpajakan atas produk-produk yang disesuaikan dengan kriteria yang berbeda, seperti : ekspor sebagai cabang dari ekonomi, fokus pengembangan ke sektor pertanian, pertambangan, manufakturing. Selanjutnya pengembangan tenaga kerja terampil dan menguasai teknologi tertentu untuk mendapatkan kualitas produk yang mampu bersaing, serta melakukan inovasi produk, berbasis sains dengan mengaktifkan riset dan pengembangan. Guna memicu peningkatan ekspor dan daya saing di pasar global, pemerintah telah memberikan berbagai jenis insentif perpajakan (tidak dipungut PPN) dan mempermudah pemeriksaan barang ekspor (Ali, 2013).

Setiap barang yang diekspor dengan menggunakan dokumen Pemberitahuan Ekspor Barang (PEB) dapat dibuat dengan benar dalam penghitungan bea keluar (apabila ada) dan lengkap semua dokumen yang terkait dengan ekspor. Isian formulir dikirim melalui media elektronik oleh eksportir atau kuasanya ke kantor pabean pemuatan paling cepat 7 (tujuh) hari sebelum tanggal perkiraan ekspor paling lambat sebelum dimasukkan ke kawasan pabean. Eksportir wajib mengisi pemberitahuan pabean ekspor dengan lengkap dan benar, dan bertanggungjawab atas kebenaran data yang diberitahukan dalam pemberitahuan pabean ekspor.

Pejabat Bea dan Cukai membukukan PEB ke dalam Buku Catatan Pabean dan memberi nomor dan tanggal pendaftaran; Atas ekspor barang curah, pemberitahuan pabean ekspor, dapat disampaikan sebelum keberangkatan sarana pengangkut. Terhadap barang ekspor yang dikenakan bea keluar, pemberitahuan pabean ekspor disampaikan setelah pembayaran bea keluar.

\section{Faktor-faktor Pendorong Kejahatan Korporasi}

Kejahatan korporasi melibatkan orang atau sekelompok orang (memiliki posisi tinggi dan terhormat) serta dampak kejahatan yang dilakukan dapat memengaruhi banyak orang (berbeda dengan kejahatan individual). Oleh karena itu prinsip societas delinquere non potest yang memandang pelaku tindak pidana hanyalah manusia alamiah (natuurlijke person) dianggap sudah tidak lagi relevan dalam ranah hukum pidana karena perkembangan model kejahatan yang tidak hanya menyangkut individu. Akan tetapi, juga tindak pidana yang dilakukan oleh badan hukum.

Akibat pengaruh yang sedemikian besar dan luas, ada empat isu utama dalam masalah kejahatan korporasi, sebagai berikut: (a) Masalah Keadilan (The Fairness Issue). Isu keadilan pada prinsipnya menyampaikan tuntutan agar hukum berlaku adil terhadap pelaku kejahatan. Hukum tidak boleh hanya menghukum pribadi yang lemah secara sosial dan membiarkan orang kuat karena memiliki akses politik dan ekonomi bebas dari jerat hukum. (b) Masalah Keseriusan Relatif (The Relative Seriousness Issue). Para pendukung gagasan pemidanaan bagi korporasi berpendapat bahwa tindakan ilegal yang dilakukan oleh korporasi lebih merugikan (baik bagi kehidupan manusia maupun perekonomian) dibandingkan dengan kejahatan konvensional. Jika kematian dan cedera akibat produk yang tidak aman, bahaya lingkungan, dan tindakan ilegal lainnya yang dilakukan oleh korporasi ditambahkan dalam daftar korban, akan diketahui bahwa kejahatan korporasi merupakan jenis kejahatan paling berbahaya di tengah masyarakat. (c) Masalah Krisis Ekonomi (The Economic Crisis Issue), korban kejahatan korporasi mendorong pemerintah agar memberi sanksi pidana yang lebih keras pada korporasi dibandingkan pelaku kejahatan konvensional. (d) Masalah Ketidakpercayaan Pemerintah (Governmental Mistrust Issue), jenisjenis tindak pidana yang dilakukan oleh korporasi meliputi manipulasi keuangan, penipuan akuntansi, penipuan makanan, kartel, suap, tumpahan limbah beracun dan bahaya lingkungan, pelanggaran hak asasi manusia, perdagangan orang dalam (insider trading), pelanggaran privasi, diskriminasi, kekerasan dan pembunuhan, serta baru-baru ini manipulasi perangkat lunak.

\section{Faktor-faktor Penyebab Terjadinya Pemalsuan Dokumen Pabean}


Dokumen-dokumen dalam perdagangan internasional adalah aspek penting yang perlu diperhatikan. Tanpa dokumen tersebut seorang eksportir tidak akan memperoleh pembayaran dan bank yang akan menegosiasi Letter of Credit $(L / C)$ tersebut. Dokumen tersebut penting bagi semua pihak yang terlibat dalam pembukaan Letter of Credit $(L / C)$, seperti eksportir, importir, dan bank. Letter ofCredit secara khusus harus menyatakan dokumen-dokumen yang disyaratkan. Dokumen-dokumen tersebut berupa: (a) Dokumen-dokumen pengangkutan: (1) Bill of Lading, (2) Air Waybill (3) ailway Consignment Note. (b) Invoice (Faktur) (1) Proforma Invoice (2) Commercial Invoice (3) Consuler Invoice (c) Dokumen Asuransi, (1) Insurance Police (2) Insurance Certificate (3) Cover Note (Sutendi Adrian, 2014).

Pada dasarnya barang-barang ekspor dibebaskan dari pemeriksaan duane. Barang-barang ekspor dapat diklasifikasikan sebagai berikut: (1) Barang bebas ekspor; (2) Barang yang ekspornya dikendalikan; (3) Barang yang dikenakan Pajak Ekspor (PE) atau Pajak Ekspor Tambahan (PET); (4) Barang yang dilarang ekspor (Marpaung Leden, 2019). Barang impor dan ekspor yang masuk ke Indonesia tidak semuanya bebas masuk, meskipun dokumen penyertanya lengkap (Firdiansyah Ryan, 2018). Adapun faktor-faktor penyebab terjadinya pemalsuan dokumen pabean, antara lain adalah: (1) Geografis, (2) Pasar produksi , (3) Masyarakat.

\section{Kebijakan Hukum Pidana Terhadap Korporasi yang Melakukan Pemalsuan Data Ekspor}

Kebijakan hukum pidana pada hakikatnya merupakan usaha untuk mewujudkan peraturan perundang-undangan pidana agar sesuai dengan keadaan pada waktu tertentu (ius constitutum) dan masa mendatang (ius constituendum). Istilah lainnya kebijakan hukum pidana dalam kehidupan bermasyarakat sering dikenal sebagai politik hukum pidana yang bertujuan untuk menyusun, membentuk dan merancang suatu peraturan yang dianggap baik dan berguna untuk masa yang akan datang.

Adanya sanksi berupa pidana ditentukan oleh ada dan tidaknya perbuatan yang tidak dikehendaki (dilarang). Suatu perbuatan yang tidak dikehendaki (dilarang) oleh masyarakat dapat diwujudkan dalam bentuk peraturan. Perbuatan yang tidak dikehendaki berupa perbuatan negatif. Artinya, perbuatan yang tidak dikehendaki secara tegas dinyatakan dilarang dalam peraturan perundang-undangan tertulis. Isi dari peraturan perundang-undangan tersebut berupa perbuatan yang dilarang atau tidak boleh dilakukan. Jadi prinsipnya, semua perbuatan itu boleh dilakukan kecuali yang dilarang. Sedangkan perbuatan yang dilarang tersebut diatur dalam berbagai bentuk peraturan atau norma yang tertulis atau tidak tertulis. Dua masalah sentral dalam kebijakan kriminil dengan menggunakan sarana penal (hukum pidana) ialah masalah penentuan: (1) Perbuatan apa yang seharusnya dijadikan tindak pidana, dan; (2) Sanksi apa yang sebaiknya digunakan atau dikenakan pada si pelanggar (Eletra, 2018). Sanksi dalam hukum pidana terdiri atas pidana (straf punishment) dan tindakan (maatregel measure). Sering dikatakan berbeda dengan pidana, tindakan bertujuan melindungi masyarakat, sedangkan pidana bertitik berat pada pengenaan sanksi kepada pelaku suatu perbuatan. Akan tetapi, secara teori, sukar dibedakan dengan cara demikian karena pidana pun sering disebut bertujuan untuk mengamankan masyarakat dan memperbaiki terpidana (Andi, 2015).

\section{Kebijakan yang Dilakukan Terhadap Korporasi yang Melakukan Pemalsuan Data Ekspor}

Direktorat Jenderal Kepabeanan dan Cukai (DJBC) merupakan salah satu institusi di bawah Kementerian Keuangan yang berperan dalam pelayanan dan pengawasan di bidang kepabeanan dan cukai. Dalam menjalankan peran tersebut DJBC dikembangkan sedemikian rupa sehingga memiliki tugas utama yakni, pengumpul pendapatan (revenue collector), trade facilitator, perlindungan masyarakat (community protector), dan industrial assistance.

Dalam melaksanakan Penertiban Impor, Cukai dan Ekspor Ilegal di Selat Malaka, Pesisir Timur Sumatera dan Batam, Pemerintah telah menyusun 11 langkah strategis yang terbagi ke dalam 3 tema besar yaitu Program Sinergi, Dukungan Sarana dan Prasarana Pengawasan, serta Operasi Bersama (Joint Operation), dengan kegiatan antara lain: (1) Penertiban pelabuhan tidak resmi guna mencegah adanya pemasukan atau pengeluaran barang ilegal dari kawasan bebas 
Batam; (2) Pengelolaan ship to ship area guna mencegah modus penyelundupan barang dengan cara pembongkaran di tengah laut dari kapal ke kapal tanpa mengindahkan ketentuan kepabeanan yang berlaku; (3) Pertukaran data terkait kapal-kapal yang berangkat dari pelabuhan, baik tujuan ke luar daerah pabean maupun antar pulau guna mempermudah pengawasan kapal yang membawa barang impor atau ekspor atau barang yang akan masuk ataupun keluar dari kawasan bebas Batam; (4) Pembentukan Maritime Domain Awareness (MDA) guna menciptakan pola monitoring yang sinergis antar instansi dalam rangka pengawasan kemaritiman; (5) Kewajiban penggunaan Automatic Identification System (AIS) bagi seluruh kapal di Indonesia guna mempermudah pengawasan kapal yang membawa barang impor atau ekspor atau barang yang akan masuk atau keluar dari Kawasan Bebas Batam; (6) Pembatasan kecepatan bagi kapal nonpemerintah atau non-militer guna menanggulangi penyelundupan dengan kapal kecil berkecepatan tinggi;

\section{Kebijakan Non Penal Terhadap Korporasi yang Melakukan Pemalsuan Data Ekspor}

Kebijakan penanggulangan kejahatan lewat jalur "non penal" lebih bersifat tindakan pencegahan sebelum terjadinya kejahatan. Oleh karena itu, sasaran utamanya adalah menangani faktor-faktor kondusif penyebab terjadinya kejahatan yang berpusat pada masalah-masalah atau kondisi-kondisi sosial yang secara langsung atau tidak langsung dapat menimbulkan atau menumbuh suburkan kejahatan. Selanjutnya penanggulangan tindak pidana kepabeanan (pemalsuan data ekspor) dilakukan dengan tindakan represif berupa penangkapan dan penyitaan. Tindakan penangkapan dilakukan oleh petugas Dirjen Bea Cukai terjadi apabila terdapat cukup bukti. Penangkapan tersebut dilakukan untuk kepentingan penyidikan ataupun penuntutan, serta peradilan menurut cara yang telah diatur dalam Undang-Undang. Adapun tindakan penyitaan dilakukan oleh penyidik untuk mengambil atau menyimpan aset untuk kepentingan pembuktian dalam penyidikan, penuntutan, maupun peradilan nantinya (Zulyadi, 2020).

Penyitaan aset inilah yang dijadikan alat bukti dalam kasus tindak pidana kepabeanan (pemalsuan data ekspor). Apabila pelaku tertangkap tangan dalam hal tindak pidana kepabeanan (pemalsuan data ekspor) maka penyidik Bea dan Cukai dapat melakukan Operasi Tangkap Tangan (OTT) dengan melakukan penangkapan dan penyitaan. Upaya penyitaan merupakan suatu hal yang penting karena penyitaan merupakan tindakan penyelamatan keuangan negara. Penyitaan merupakan suatu tindakan antisipasi dari aparat penegak hukum dan dinilai dapat meminimalisasi kerugian negara. Penyitaan tersebut berupa aset-aset yang dimilik oleh tersangka tindak pidana kepabeanan (pemalsuan data ekspor). Penyitaan ini dapat dilakukan oleh PPNS Dirjen Bea Cukai pada saat penyidikan tahap awal.

Berbicara mengenai pertanggungjawaban pidana, maka tidak dapat dilepaskan dengan tindak pidana. Walaupun tindak pidana tidak termasuk masalah pertanggungjawaban pidana. Tindak pidana hanya merujuk kepada dilarangnya suatu perbuatan. Dasar adanya tindak pidana adalah asas legalitas, sedangkan dasar dipidananya pembuat adalah asas kesalahan. Ini berarti bahwa pembuat tindak pidana hanya akan dipidana jika ia mempunyai kesalahan dalam melakukan tindak pidana tersebut. Kapan seseorang dikatakan mempunyai kesalahan. Ini berarti bahwa pembuat tindak pidana hanya akan dipidana jika ia mempunyai kesalahan dalam melakukan tindak pidana tersebut (Teguh, 2011).

Undang-Undang Kepabeanan yang baru (UU No.17 Tahun 2006), terjadi fase perubahan norma pengertian penyelundupan. Jika dalam UU Pabean yang lama pengertian penyelundupan hanya jika sama sekali tidak memenuhi ketentuan, maka dalam UU baru diurai menjadi 13 norma yang dapat dikategorikan sebagai ekspor atau impor. Secara lengkap Pasal 102 A UU Pabean mengatur mengenai sanksi pidana terhadap penyelundupan dibidang ekspor, pasal tersebut pada Undang-Undang kali ini memiliki kualifikasi khusus untuk ekpor. Secara lengkap Pasal 102A UUP mengatur mengenai sanksi pidana terhadap penyelundupan dibidang ekspor.

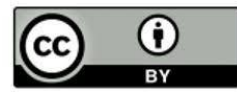




\section{SIMPULAN}

Berdasarkan hasil penelitian tentang "Pertanggungjawaban Pidana Korporasi Terhadap Pemalsuan Data Ekspor Zinc ash Yang Dilakukan Oleh Pt Marakes Jaya Abadi (Studi Riset KPPBC Belawan)", maka dapat ditarik kesimpulan sebagai berikut: Aturan hukum yang mengatur tentang pertanggungjawaban korporasi dalam peraturan perundang-undangan terhadap pemalsuan data ekspor zinc ash adalah sebagai berikut: (1) Pengurus dan orang lain yang mewakili pengurus seperti terdapat pada Pasal 15 ayat (3) Undang-Undang Darurat No. 7 Tahun 1955 dan Pasal 20 Undang-Undang No. 20 Tahun 2010. (2) Korporasi, ketentuan ini diatur dalam Pasal 15 ayat (1) Undang-Undang Darurat No. 7 Tahun 1955, Pasal 20 Undang-Undang No. 20 Tahun 2001, Pasal 6 Undang-Undang No. 8 Tahun 2010. (3) Faktor penyebab terjadinya pemalsuan data zinc ash yang dilakukan oleh korporasi adalah sebagai berikut: Faktor-faktor penyebab terjadinya pemalsuan dokumen pabean, antara lain adalah: (a) Geografis, (b) Pasar produksi, (c) Masyarakat. Kebijakan Hukum Pidana Terhadap Korporasi Yang Melakukan Pemalsuan Data Ekspor Adalah Sebagai Berikut: (1) Sanksi apa sebaiknya digunakan atau dikenakan pada si pelanggar. Menurut marjono reksodipuro terdapat tiga sistem pemidanaan yang terkait dengan korporasi yaitu: (a) Pengurus korporasi sebagai pembuat dan penguruslah yang bertanggungjawab; (b) Korporasi sebagai pembuat dan pengurus bertanggungjawab; (c) Korporasi sebagai pembuat dan juga sebagai yang bertanggungjawab.

\section{DAFTAR PUSTAKA}

Amiruddin. (2018). Pengantar Metode Penelitian Hukum. Depok: PT. Raja Grafindo Persada.

Arfin. (2019). Pengantar Pengawasan Kepabeanan. Bogor: Ghalia Indonesia.

Bahder, J. (2008). Metode Penelitian Ilmu Hukum. Bandung: CV. Mandar Maju.

Ediwarman. (2020). Tindak Pidana Pencurian Ikan di Kawasan Selat Malaka Dalam Perspektif Kriminologi. Yogyakarta: Genta Publishing.

Eva, S. (2015), Pertanggungjawaban Pidana Pelaku Tindak Pidana Penyelundupan di Indonesia. Jurnal Mercatoria Vol 8 No 1/Juni 2015, diakses pada tanggal 20 Maret 2021, pada pukul 19.30. Wib.

Marpaung, L. (2019). Tindak Pidana Penyelundupan, Masalah dan Pemecahan. Jakarta: PT Gramedia Pustaka Utama.

Purwito, A. (2010). Kepabeanan dan Cukai, Pajak Lalu Lintas Barang Konsep dan Aplikasi. Jakarta: Kajian Fiskal FHUI.

Purwito, A. (2013). Kepabeanan Indonesia; Konsep Kebijakan dan Penerapan. Tangerang: Jelajah Nusa.

Rizkan, Z. (2020). Kerangka Teori Dalam Penelitian Hukum. Medan: Enam Media.

Ryan, F. (2018). Pengantar Kepabeanan: Imigrasi dan Karantina. Jakarta: Mitra Wacana Media.

Subagyo, J. (2009). Hukum Laut Indonesia. Jakarta: Rineka Cipta.

Sutendi, A. (2014). Hukum Ekspor Impor. Jakarta: Raih Asa Sukses.

Wibowo, Y. (2018). Tindak Pidana Penyelundupan di Indonesia; Kebijakan Formulasi Sanksi Pidana. Jakarta: Sinar Grafika.

Widya, M. (2017), Tindak Pidana Penyelundupan di Bidang Ekspor Impor Ditinjau Dari UU. No 17 Tahun 2006 Tentang Kepabeanan. Jurnal Universitas Pelita Harapan, Krawaci, 2017, UPH, halaman 1-2.

Zulyadi, R. (2020). Perlindungan Hukum Terhadap Anak Sebagai Korban Perdagangan Manusia. Medan: C.V Pustaka Prima. 